\title{
The Political Practice and its Subjects in of New Critical Theories: Complicities and Points of Adversity
}

INDA, Graciela

Instituto Multidisciplinario de Estudios Sociales Contemporáneos (IMESC) / Instituto De Estudios Históricos, Económicos, Sociales e Internacionales (IDEHESI) Consejo Nacional De Investigaciones Cientificas y Técnicas (CONICET); Facultad de Ciencias Politicas y Sociales Universidad Nacional de Cuyo, Mendoza. Argentina.

Correspondence to (gracielainda@conicet.gov.ar)

PUBLISHED: 08/12/2021

ACCEPTED: $\quad 07 / 12 / 2021$

SUBMITTED: 26/11/2021

\section{COPYRIGHT NOTICE:}

(C) 2021 by author. Licensee ERUDITUS. This article is an open access article distributed under the terms and conditions of the Creative Commons Attribution (CC BY) license (https://creativecommons.org/licenses/by/4.0/).

\section{CITE THIS PAPER:}

Inda, Graciela 2021. "The Political Practice and its Subjects in of New Critical Theories: Complicities and Points of Adversity" Journal of Social Sciences: Transformations \& Transitions (JOSSTT) 1(02):06. DOI: https://doi.org/10.52459/josstt1261221

\section{ABSTRACT}

These four theoretical bets on the "multitude" (Hardt and Negri), on the political subject as fidelity to an event (Badiou), on the "people" as a hegemonic interaction of heterogeneous demands (Laclau and Mouffe), on the political subject as an emergent subject of an egalitarian irruption (Rancière), illustrate the seek for new political subjectivities after abandoning the Marxist thesis that gives a decisive role to the working-class in the process of social transformation. Apart from this binding nucleus, they present divergences that place the question about the subject of emancipation in a field of confrontations, and bifurcation points.

This work aims at delimiting the lines of combat, voices of consent and dissent found in these new critical theories regarding the connection between political subjectivity, and economic relations, the issue of the strategy, the nationalism/internationalism dilemma and the disjunction between statism and anti-statism.

\section{KEYWORDS}

New Critical Theory; Social Classes; Political Subjects; Social Transformation; Capitalism; State. 


\section{INTRODUCTION}

The proliferation of the emancipatory subjects is a distinctive coordinate of the new critical theories emerging from the defeat of great popular movements from the 60s and 70s that became known after the Fall of the Berlin Wall. In opposition to the Marxist conviction that gives a decisive role to the working-class in the process of social transformation, this new critical political cartography ${ }^{1}$ explores which types of subjectivities, new articulations or political subject/s dominate the scene in current capitalism.

These new critical theories were formed in the opened space by the crisis of the communist tradition and by the criticism about the lack of ground of the Marxist definitions on politics and State. They came from Western Marxism and its derivations and most of them do not follow a Leninist conception of power centered in the State, of the concomitant strategy of a frontal struggle in a situation of dual power and also of the formula of a political party of the working-class as the privileged agglutinant of the historical transformation.

The theoretical bets on productive and cooperative multitude (Hardt and Negri), on the political subject as fidelity to an event (Badiou), on the people as a hegemonic interaction of heterogeneous demands (Laclau and Mouffe), on the political subject as an emergent subject of an egalitarian irruption (Rancière), illustrate that these new subjectivities or multiple interactions displaced the political centrality of the workingclass in current conditions of capitalism. This way and against those postmodern theses announcing the end of politics with a deep distrust of the great emancipatory projects, the political practice and its subjects were rescued, but keeping distance from the Marxist subject.

Nevertheless, beyond these common problems, the alternative theories to the Marxist project mentioned above, all of great impact and resonance in the last decades, maintain differences and weighty discussions among themselves. It can be stated that they do not coexist peacefully and happily. As will be shown below, the question for the emancipatory subject implies several confrontations and points of bifurcation among them.

Considering as the raw material for this paper that partial but revealing repertoire of some of the most impressive responses that the so-called crisis of the subject produced in the geography of the new critical theories, the objectives of this work are four: 1-identifying, in each case, how the relationship (or norelationship) between political subjectivity and economic relations is presented; 2- analyzing what forms of

\footnotetext{
${ }^{1}$ According to Keucheyan (2013), the various readings that question the contemporary capitalist order, wonder about the conditions of possibility of an emancipatory political practice, and drift away from the different neoconservative visions celebratory and neoconservative, can be included under the heading of new critical theories. The always problematic term "new" does not pretend to ignore that they are involved in inherited discussions and in the re-elaboration of previous theories but to emphasize that they started to play a central role in the theoretical-political debates from the nineties onwards.
} 
activity and deployment are assigned to each political subject (the question of strategy); 3 - to elucidate if political subjects are shaped following a global context or if they are constituted and mobilized in the local and national field (the nationalism/internationalism dilemma); 4- analyzing the type of relationship established between the political practice and the State apparatuses, that is, if it is possible that popular forces or multitude struggles can generate effective power in the State field, or if they are caught to remain entrapped in its domination mechanism, which leads to the problem of liberal democracy as an appropriate field for emancipatory political practices, or a field exclusively at the service of capital accumulation (the statism or anti-statism dilemma).

This work is far from seeking a detailed examination of each theoretical position, an attempt certainly impossible in this instance since each of them forms a multidimensional theoretical body of great scope and complexity. The main goal of this intervention is to delimit the lines of combat that are drawn between them taking as pivots the four concerns mentioned above.

Assuming that all the texts under analysis are parts of a theoretical-political dispute about the definitions of political practice and its subjects, the focus of the reading will be put on mutual references, either explicit or implicit, and on their complicity or confrontation without disregarding all the problems implied by these positions ${ }^{2}$.

\section{The Dilemma of The Connection Political Practice/Economic Practice}

Confronted with the problem inherited from the Marxist belief between the connection among economic relations and political practice, all the theories studied here reacted by keeping distance from Marx's thesis on the ultimately determined by the economic instance, from the idea of the main antagonism between the bourgeoisie and the proletariat and from the supremacy of the working-class - defined according to a criterion of productive work or generator of surplus value creator-over the other social classes or fractions dominated by an anti-capitalist front.

However, this reaction takes different paths. While Laclau, Mouffe, Rancière, and Badiou stand for the autonomy of politics, Hardt and Negri locate directly the political subjectivity in the productive world, not without first redefining the Marxist concept of productive work.

According to Laclau and Mouffe (1985), the expansion of the antagonism and the emergence of new political subjects come from the democratic revolution that started in the seventeenth century and from its

\footnotetext{
${ }^{2}$ In this article, it is deepening and returning into some proposal and concerns made in Inda (2018) and Inda (2019).
} 
imaginary egalitarian effect to different spheres of social life. From this perspective, many working-class and socialist struggles in the nineteenth century are built discursively from the struggles for political freedom.

A political practice does not express any given class interests, it actually requires a hegemonic operation that shows individual interests as general ones. There is not any central conflict inherent to the process of surplus value extraction or previous identities to the political practice. In order to produce an antagonism, for example, workers must resist and denounce their unfair situation from an external speech. The "people" are the unstable effect of a political construction and it is not a block derived from the social structure. Besides, it does not name a given actor, but it creates a historical agent. Finally, it does not aim at a form of mobilization or the ideology of a constituted group, but it refers to the form of constitution of said group (Laclau, 2000, 2005).

Politics, in short, involves the construction of collective identities, the creation of a "we" as opposed to a "them", in precarious and modifiable forms because it takes place in a dimension of antagonism and hostility that is inherent in social relationships. The political, in addition, is not located at a level of social order or is determined by one another; however, it does have a foundational and articulatory nature of social relations.

According to Rancière (1995), politics expresses an eminently egalitarian discursive process with an antagonistic logic that halts the divisions set by the police. The "people", as subjects of politics, are a mode of subjectivation that challenges the fixation of the places assigned by the social structure and the State, turning them into objects of litigation and opening a space that anyone can take up.

Politics does not express a latent subject as it is in the scheme of the multitude. It actually arises when a group that has not been taken into account, seeks to build a "we" open to anyone, regardless of their social class. The "people" are not an economic group that becomes aware of itself. Moreover, it has no existence as a real part of society prior to the political declaration by which it is constituted. The parties do not pre-exist the conflict because the latter can only be appointed by them (Rancière 1995). The proletarian political subjectification of the early nineteenth century, for example, designates a productive class that finds its conscience from a multiplicity of events (discussions, strikes, newspapers, pamphlets) and not from political party leadership. This consciousness is what makes the worker feel powerful to claim his equality through declarative acts (Rancière, 1981).

Badiou (1985) considers that although the class-based character of our society is the general element where the political question is placed, it does not prefigure political paths nor does it indicate an emancipatory subject. Politics cannot be reduced regarding the economic infrastructure and it cannot be thought to be a concentrate of the economy, as the Leninist model proposes. It does not represent the proletariat, the class, or 
the Nation. We can't assume that politics first exists and then, it can be represented. Same as Rousseau's idea, the "people" do not preexist the contract by which it is constituted with political capacity, the proletariat exists as a political subject because of its effects, due to the interruption it produces in a chain of representations.

Political subjectivity is not the internalization of an economic objectivity of class according to Badiou. For him, political subjectivity must be conceived as a practice that can be thought from itself and according to its own principle of internal ordering.

The ability to become a political subject implies the subject's recognition (e.g. the militant) of an event that is by definition unpredictable and revulsive of the existing collective coercion and the capitalist complex ${ }^{3}$. Moreover, the authentic political event requires the experimentation of the communist hypothesis as the only way against the deep depoliticization of capitalism. The political subject is the bearer of an egalitarian axiom and an aspiration of anti-capitalist emancipation (Badiou, 1988; Badiou, Gauchet, 2014).

Facing the positions that claim the inaugural nature of politics, Hardt and Negri (2000) affirm that the new proletariat (or multitude), inherently endowed with the ability to resist the domination of capital, emerges from the very heart of the process of computerization of capitalist production characterized by the central place of knowledge and communication.

The productive multitude not only includes the class that produces the surplus value but it also covers all forms of work (female reproductive work, agricultural work, the unemployed work, cooperative work, etc.), without any of them having political priority because they all produce constantly everywhere, and they share the same potential of insubordination (Hardt, Negri, 2004).

Within the field of production, the hegemonic position previously exercised by the industrial working class over other forms of work has been displaced by the primacy of intellectual and cognitive elements in the definition of labor power. Although in quantitative terms, agricultural work continues to be dominant and industrial work has not declined, the immaterial work set the new work trends: they are computerized, organized in networks and communicative. These modalities of productive cooperation founded a new way of resistance because they were not created by the capitalist as part of his project of work organization, but they resulted from the productive energies of work itself (Hardt, Negri, 2000, 2004).

Although they have emphasized on different occasions that it is necessary to think about the transition from potentiality to the conformation of a constituent political subject, they also highlight that making the

\footnotetext{
${ }^{3}$ The faithful subject and the event have the same origin, none can exist without the other, because the event requires being named by the subject and the subject is born to himself in a collective process capable of determining a common vision (Badiou, 1988).
} 
decision is immanent to the emerging multitude of the world of production. In the same way and with the same capabilities with which the multitude produces economic values, it can make political decisions (Hardt, Negri,

\section{The National/Global Dilemma}

As it is known, Negri and Hardt argue that after the collapse of the colonial regimes and the fall of the barriers raised by the Soviet bloc to the world market, a new empire was formed that was qualitatively different from the old imperialism defined by the territorial expansion of the national states. The new form of imperial sovereignty is flexible, mobile, and crossed borders and limits. It gives shape to an off-centered world, in which no potency is definitively imposed y where the ultimate authority resides in large multinationals and their agencies instead of national States (Hardt, Negri 2000, 2001).

Under the new conditions, the functions that States retain, such as those of securing the legal, administrative, and monetary schemes necessary for the international flow of capital and setting in motion the local repressive and disciplinary mechanisms to control the struggles of workers, are not determined by national or regional interests, but increasingly by the needs of the imperial power (Hardt, Negri, 2004).

Considering this diagnosis, are strategies and political subjects of resistance to global power seeking for recovering national sovereignties valued? No way. The struggles against the empire can only come from an equally decentralized and global subject that overcomes the divisions among the masses of the planet based on national identities. Only a labor force moved thanks to emigration, nomadism, miscegenation, and exodus can shake the parasitic and passive structure of the empire. That imperial structure is sustained by the creative and cooperative forces of the multitude and does not choose its own dynamics, but it is built in reaction to the intensity of the social movements that corral it (Hardt, Negri, 2000).

The conformation of the multitude as a political subject, that is, with the capacity to make decisions and act in common, depends on the communication through time and space of the multiple movements and resistances. Only by intensifying each of the local struggles and articulating them with new ones, a constituent power opposed to the empire can be built at a global level (Hardt, Negri, 2004).

The authors argue that every formula of national liberation produces an impotent mobilization of the popular forces before the structure of global power that ends up being channeled by the power of the national State. There is no way for the popular classes to build their own power from the institutions of the national State, not even in the periphery of capitalism because political life is trapped in the state body (Hardt, Negri 
2000). We must abandon the slogan "take power", based on a misconception of power as concentrated in the State (Negri, 2010) and consider that to become strategic, the struggles need to adopt a world point of view and find global circulation connections (Negri, 2001).

In opposition to the verdict of a new era characterized by the de-imperialization and decentralization of economic power, Badiou claims that far from being a recent and specific phenomenon of our times, globalization is coeval and inseparable from capitalism. Since a few decades ago, that we have returned to the primitive accumulation of capital in a magnitude that was previously restricted by the communist alternative that blocked the expansion of the world market (Badiou, Gauchet, 2014).

Imperialism has not disappeared; it has only changed its form. After colonialism, we find the anarchy of zones, that is, a strategy of generalized looting through the creation of monopolistic strategic enclaves, taking advantage of the weakness of the states and contributing to it. The current globalization must not be identified with a post-state era where all the actors have the same decision-making power: The United States continues to be the systemic center of the world capitalism (Badiou, Gauchet, 2014).

Although these two representatives of the so-called radical left disagree on their diagnosis (a new form of deterritorialized sovereignty vs. imperialism of zoning), and on their conceptions of the political subject, they do agree on a key point: emancipation can only be global.

Badiou (2007) assumes that the world of capitalism and rich democracies is actually a false world, which only recognizes the unity of products and monetary signs and throws most humanity into "another" devalued world separated by walls and wars. Consequently, affirm that "there is only one world" constitutes a principle of action, a political imperative for the equality of existence that it does not contradict the infinite game of identities and differences.

Badiou claims that only internationalism, defined as a conjunction of initiatives against globalization, would prevent a popular movement from ending up serving the globalized capital. The proletarians, more nomadic than ever, have no homeland and constitute the living body of internationalism. We must be alert to the use of the word "people" when it is followed by an adjective that defines a national identity since it constitutes a category of the State that designates all those who belong to the so-called group "people", compared to others who are excluded (Badiou, 2013).

The real scale of political construction is worldwide. Although popular movements always have a local inscription, in terms of their overall vision, their space of experimentation, failure or success, they must catch up with their adversary, capitalism, which is a global force (Badiou, Gauchet, 2014). 
While Hardt and Negri focus on the geographical propagation of anti-capitalist movements by close contact in communication, Badiou (1982) understands that a sum of rebellions is not enough to conform a subject and requires an instance of organization and orientation that winds up the partisan scheme and it must be immersed in society.

Rancière (1995) intervenes in this debate by claiming that currently state power is impotent in the face of the global need of the capital that dominates it and that it bases its legitimacy on this absence of choice. The State no longer hides its complete dependence on global capital but bases its authority on its capacity to manage the inevitable crisis, the tiny but decisive difference that separates the current situation from a scenario of threatening misery and chaos.

But he also notes that the constitution of a "people" as a collective subjectivation is connected to the national space. Although capital is a global power, the egalitarian symbolizations that lead to the constitution of a political subject operate at local emergency points and refer to a domination that is exercised in a national space (Rancière, 2016).

The theoreticians of populism Laclau and Mouffe believe that political subjects are constituted within the national states. They also consider the liberal and national democracy constitutes the historical terrain of emergency of collective struggles aimed at fighting against inequalities and questioning relations of subordination ${ }^{4}$.

They even admit that under certain conditions, political subjects can be constituted from the action of the national States. The populist movements that emerged in Latin America after the crisis of the thirties, for example, developed essentially as state populisms, that is, from the intervention of strong national States that were against the oligarchic power (Laclau, 2005).

The most distinctive quality of globalized capitalism as a new stage in the history of capitalism is the multiplication of disruptive effects and the proliferation of new antagonisms, a process that imposes on every anti-globalization political movement the tasks of articulating heterogeneous social demands and producing a common language. There is no anti-capitalist struggle per se, but rather anti-capitalist effects that can lead to the articulation of a plurality of struggles. What you have to ask yourself, says Laclau (2005), is whether global anti-capitalism constitutes (or not) an empty significant that contributes to the unification of the field of anticapitalist equivalences.

\footnotetext{
${ }^{4}$ These authors claim that the struggle against subordination cannot result from our own subordination. A political action is in charge of transforming a relationship of subordination into a relationship of oppression where an antagonism takes place. A discursive exterior must be present in any relation of oppression from which subordination can be interrupted (Laclau, Mouffe, 1985).
} 
Rejecting categorically the idea of a productive multitude endowed with an immanent power and with a tendency towards rebellion, Laclau (2001) foregrounds the inescapable power of a political action and its contradictory nature. The "people" is by nature imprecise and fluctuating because it results from a discursive political-articulatory practice of heterogeneous demands around an empty significant constituent without any prior social or ideological basis. Therefore, it can be a right-wing populism or a left-wing populism. A populist operation does not mean "people" because global emancipation is not guaranteed and depending on the historical context, we can be talking about a reactionary subject instead of an emancipatory one. In a recent book, Mouffe (2018) fully addresses this issue by proposing a left-wing populism that draws a frontier with the right-wing populism, tipping the scales in favor of equality and a radical and plural democracy.

At this point, Laclau (2005) argues with Rancière. Although he values his definition of the "people" as an irruption of an egalitarian declaration, he considers that he is wrong when he assumes it as a full possibility of an emancipatory politics, without considering the possibility that the "uncounted" may construct their "uncountability" following, for example, a fascist direction.

\section{The Spontaneity/Organization Dilemma}

The potential power of the multitude becomes effective power is a process that depends on the intensity and expansion of different microscopic and partial struggles and it cannot be guaranteed (Hardt, Negri, 2004). They can accumulate and strengthen each other until they reach a threshold of realization according to their power or, on the contrary, be trapped to mechanisms of subjection, division, and repression produced by the economic power and the state institutions.

It depends on an alternative political project to the Empire's rule that the struggles become stronger and that new intellectual workers' complaints are connected to the factory-workers' ones. The multitude becomes a subject just in those cases when actions fuse together in proposals of political resistance ${ }^{5}$ (Hardt, Negri, 2000). This change does not result from an organizational commando (party, leader, etc.) or from a spontaneous harmony but from the common interactions and experiences (Hardt, Negri, 2004).

Negri (2001) states that a counterpower strategy implies three moments: firstly, the daily resistance developed by different subjects in several spheres of social life; secondly, the uprising which takes place when a popular movement merges different resistance forms in a common political project and thirdly, this

\footnotetext{
${ }^{5}$ They mention as examples the anti-globalization movements, the movements for peace, the movement for civil disobedience, the actions for the rights to global citizenship, a guaranteed social wage and income, the re-appropriation of the means of production, free access to knowledge, information and communication, among others.
} 
constituting power that organizes positively new ways of living. If they are not connected, these resistances can be manipulated and controlled, and the uprising can be crushed if it is not popular and lacks a constituting imagination. This triad resistance/uprising/power can work when it is conceived as a strategic device used to overcome all the operations carried out to abort it or to turn it in favor of the capital and the established political power.

The ultimate objective of this counterpower process is the creation of a new type of Communism defined by new forms of freedom and democratic participation. In other words, it is a self-government without the necessity of leaders that manages the common wealth without resorting to private property.

Although Badiou coincides with Hardt and Negri's program in the necessity of a global dimension in the anticapitalistic fights, he moves away from them when he focuses on the problem of the direction and organization of those fights. The communists, as members of a general preexistent movement, have the goal of guiding the group's dynamics and set the limits of the possible political forms enabled by the juncture. They must combine the theoretical dimension with the local actions that embody the communist principle and merge these heterogeneous groups: the rebellious university youth, the populist youth that resists in different parts of the world, the international nomad proletariat, and the precarious proletariat all over the world (Badiou, Gauchet, 2014).

A spontaneous movement is not enough. In uprisings or resistance movements, there are always conflicting policies and even representatives of the enemy. The political decision for collective equality must also reject the dominant ideology and the rules of power. The strength of the revolt combined with the logic of discipline (Badiou, 2003). The new relationship between the objective and the subjective should not be a multiform movement inspired by the intelligence of the multitude nor a renewed traditional party (Badiou, 2007).

Laclau and Mouffe (1985) not only reject the notion of the multitude as a decentered and immanent subject but also that of a vanguard party, which they regard as manipulative. According to them, a vanguard party can only respond to the various democratic demands of mass struggles with political authoritarianism based on its identification with the interests of the working class, defined as the universal class and the depositary of knowledge.

The nature of the different forms of political organization (e.g. political parties and trade unions) must be analyzed in the context of each historical period. Sometimes, they may establish a bureaucratic apparatus and open up a sharp divide between rulers and ruled that prevents the emergence of mass movements, while other times they agglutinate scattered and depoliticized groups (Laclau, Mouffe, 1985). 
A democratic strategy to seize power should rely on a chain of equivalence among the various struggles against subordination, so that the interests of workers, for example, are not advanced at the expense of the rights of women, immigrants, consumers, etc. In addition to this, pluralism and respect for individuality can only exist if the demand for equality is balanced by the demand for liberty. Neither the (impossible) logic of final identity nor that of pure difference, but a democratic movement capable of acknowledging both multiplicity and the need for ongoing political articulation (Laclau, Mouffe, 1985).

If peripheral groups with a weak will of their own and anarchic democracies (e.g. indignant or antiglobalization movements) are not able to take some sort of institutional form, they break up without producing any political effect (Laclau, 2010). Popular movements, therefore, keep "walking between precipices" because excessive institutionalization leads to their fossilization, while a complete disarticulation leads to political impotence (Laclau, 2009).

The theoreticians of radical democracy reject the idea of revolution as an exceptional founding moment. They stress that any emancipatory project should acknowledge that in liberal democracies the articulation between equality and liberty is always contingent and open to new forms of articulation (Mouffe, 2000; Laclau, 2005). Market-oriented and other neoconservative projects focused on consumer individualism must be challenged with the expansion of egalitarianism that started with the French Revolution. The transformation of the capitalist relations of production that underlie the different types of subordination is one of the moments of a radical democratic project, and not the other way around (Laclau, Mouffe, 1985).

On the other hand, Badiou believes that the only way to embark on a process of social transformation - defined as the end of capitalism and its institutions - is to implement a type of politics (which may opt for singular forms depending on the historical juncture) inspired by the egalitarian principles of communism. It is all or nothing. If the communist hypothesis is not feasible, if it's not the ultimate objective of the struggle, then, no collective action is really worthwhile.

Throughout history, from slave revolts to mass actions, communism is not a utopia or a program; rather, it is a set of intellectual representations that work as the horizon of any initiative (regardless of how local or limited). Political actions compatible with such a horizon are emancipatory, otherwise, they are reactionary (Badiou, 2007).

In the sequence that started in the late ' 70 s, which was marked by the imposition of the capitaloparliamentarian State, the communist hypothesis can no longer pass as a radical insurrectional change led by the masses or the working class. As in the 19th Century, it is not the victory of the hypothesis that is at stake but its conditions of existence. Therefore, the strategy to renew the communist hypothesis in the militant and 
ideological field is to combine local and singular political actions (which are unpredictable) with thought processes, which are always global or universal (Badiou, 2007).

For Rancière, however, the political subject is not the bearer of a program because, from his perspective, the subject that gives rise to politics is as consistent as the set of operations and experiences designated by such politics. Declarations of human rights and national constitutions, for example, are effective — but weak and ephemeral — ways to assert "peoples"" rights. Their ultimate objective is to extend that power in political litigation to demonstrate the difference of the "people" with itself (Rancière, 1995).

When Rancière (2013) refers to the people as being capable of putting into practice an egalitarian principle by claiming the part of those who have no part, he is thinking about a specific figure. There are some figures of people and populism (managed by the power of the State) that are the complete opposite to this capacity: the people as a herd led by good shepherds, ignorant people oligarchs keep at a distance, the people as the enemy of others (racism).

In this regard, Rancière agrees with Hardt and Negri (2001), who believe that the contractual figure of the people as the repository of sovereignty is just a representation made up of State institutions that turn multiplicity into a regulated and controlled unit. As Badiou (2013), Rancière is also suspicious of all definitions of the "people" based on a national identity outlined by the State, which, by definition, is based on the exclusion of others.

According to Rancière not all collective demonstrations or protests taking the streets are potentially emancipatory. Real political action can only stem from strong movements of action that embody the power of anybody (i.e. everybody and anybody), that take the side of the universal and cannot be monopolized by any single group, be it the oligarchy or the working class.

He rejects both the idea of a multitude that emerges from the world of production and partisan organization schemes; rather, he is in favor of mobile, intermittent, non-identitarian subjectivities. Instead of embracing a specific formula, Rancière provides us with some insights into how to attain long-lasting relationships and stable institutions for the democratic administration of the commonality [le commun]. Firstly, he considers that the fight for the commonality [that which is common] cannot be separate from its organization. For him, subordinating the administration of community problems to a strategy aimed at seizing and taking power would be a great mistake. Secondly, he states the need to acknowledge the intrinsic value of the egalitarian forms of counter-society (i.e. production cooperatives, collective forms of life, etc.) that can take shape in a non-egalitarian society. Thirdly, as for the kind of organization required for that process, he states that current democratic movements should build the field of what is common 'from scratch' (Rancière, 2014). 


\section{The Statism/Anti-statism Dilemma}

The theoreticians of populism believe that struggle movements cannot be completely alien to the State; otherwise, they are bound to political impotence. Badiou, however, shows an aggressive kind of anti-Statism. Politics are not a means to seize the power of the State; rather, politics should be able to exist on their own and to express their disagreement with and independence from the different forms of State violence and omnipotence (Badiou, 2003; Badiou, Gauchet, 2014).

Rancière (1995) also aligns with anti-Statist views. Even though he acknowledges that there is a worse and a better police order (the expression he uses to refer to State activities) — and that the second may be kind and even bring benefits for citizens and is preferable to the first-, its nature is the same: the police refers to the set of procedures (including but exceeding repression and ranging from judicial and healthcare to cultural institutions, among others) to distribute the places and roles of each group and organize consent. According to Rancière (1997), politics is not the exercise of power, but an expression of dissent. Its essential task is to arrange its own space and establish the visibility of its subjects.

The rights and liberties observed in the sphere of the State do not come from legislators or State administration; rather, they emerge from the fractures through which the egalitarian logic divides the police community from itself (Rancière 1995). The egalitarian principle that defines politics always emerges as a reaction against the State's principle to confiscate collective power. Rancière states that it is necessary to protect the autonomy of movements from partisan and union organizations and from State systems.

As stated before, Hardt and Negri claim that the State - although retreating before transnational economic power, still performs a decisive role in containing and isolating resistance struggles by transforming the multitude (characterized by diversity) into contained controlled "people".

Following Spinoza, Negri states that the counterpower of the multitude and the established power of the Empire are not equivalent. According to Negri, counterpower strategies should never be aimed at taking power; rather, they should develop a new power of life, organization, and production (Negri, 2001). A multitude capable of opposing the Empire without intermediaries aspires to build a counterpower external to the forces of capital and the Empire.

In the light of the neoliberal ambition of privatizing what is common, administration and regulation by the State is not a real alternative (Hardt, Negri, 2009). They propose creating a concept of privacy based 
on the singularity of social subjectivities rather than private property, and a concept of public based on what is common and not on State control (Hardt, Negri, 2004).

As we have already observed, Laclau's notion of people (2005) includes an egalitarian dimension because it always originates from deprivation or exclusion and protests against the established order. However, the "people" are not completely external to the democratic liberal State and its institutions, since it is impossible to build a popular and democratic will without representative mechanisms.

Badiou does not agree with the advocates of democracy liberal. He considers that parliamentary democracy — with its alleged political representatives who answer to economic powers, its election processes aimed at maintaining the established order, its mechanisms to alternate opponents that are not materially different from each other (the defense of private property versus public good) - prevents any significant political change from actually taking place. Far from setting the necessary conditions to challenge capital, this democracy is based on individual competition and the atomization of the political subject that, therefore, is identified with the buyer-seller that appears before the market (Badiou, Gauchet, 2014).

If the sphere of the State is only about citizens' right to vote, parliamentary democracy cannot pave the way for an emancipatory form of politics (Badiou, 1982). Therefore, any radical opposition to the power of capital is about seriously challenging democratic pluralism, i.e. the set of subtle and small differences tolerated by capital (Badiou, Gauchet, 2014).

According to Badiou, we should not stop using the word democracy altogether; rather, we must separate it from its capitalist deception and embrace its true nature: democracy as equality before the political Idea. Contrary to all democratic and representative projects, communism is the only good hypothesis to conceive an emancipatory politics (Badiou, 2007).

Like Rancière, Badiou considers that the type of democracy that prevails in contemporary societies, which he calls consensual or post-democracy, fully identifies with the administration of capital and preserves the status quo in social relations, annihilating the "people" as a disruptive political subject (Rancière, 1995).

In their discussion, Rancière states that in post-democracies the principle of representation is almost vacuous because it has been privatized by economic powers and absorbed by the State. Democracy is neither a set of institutions (the rule of law) nor a type of regime (parliamentary regime) among many others; rather, it is an autonomous form of existence of the people (Rancière, 1995).

Hardt and Negri also criticize existing democracies. As stated before, they believe that existing representative mechanisms result in the production of "One "people". Not only are these democracies just a 
moment to select the member of the dominant class that will create the illusion of representing the "people" but have also become unfeasible. The power of the Empire and its supranational economic institutions increasingly operate without making use of the mechanisms for popular representation and hinder the creation of national political spheres where sovereign "people" can be represented as such (Hardt, Negri, 2001).

The current crisis of democracy - they state - is acknowledged and denounced by the massive demonstrations against globalization that demand actual participation and a democracy built from the bottom up, opposing to the corrupt democracy that became the political face of capitalism or the regime of bureaucratic elites (Hardt, Negri, 2004).

Still, these authors are not pessimistic. Every day, the relationship of sovereignty develops political relationships that resemble the economic relationship between capital and labor, because just as capital depends on productivity, imperial sovereignty depends on subjects' productivity and social consent. The governed], though exploited cannot be excluded because if they reject the power relation the Empire will collapse like a lifeless body (Hardt, Negri, 2004).

A return to socialism - which they consider obsolete - is not a solution (Negri, 2010). The only way out is to search for new forms of democracy that are not based on representation or that are based on new forms of representation capable of acknowledging the multiplicity of the multitude and its active nature for it not to be treated as an easy-to-manipulate mass (Hardt, Negri, 2001).

All in all, they vindicate the practice and the theory of communism as a movement of radical criticism of the existing order. Hardt (2012) does not conceive communism as an exaltation of the State but as its abolition: not as the abolition of political dissent and freedom of speech, but as the process of experiencing forms of freedom and democratic participation unprecedented in contemporary societies.

\section{CONCLUSIONS}

Abandoning the Marxist premise of an organic link between (class) economic and (class) political position, far from adopting homogeneous forms in the new critical cartography, raises confronted positions.

On one hand, one position places great trust in the autonomy of politics and of the subjects that emerge from and for it. Whether defined as a mode of subjectivation that challenges social structure and the State's police order (Rancière) or as the effect of an event dissociated from classes, the economy, or the state apparatus (Badiou), the notion of people takes shape in synchrony with a political action that can only be conceived from its own perspective. Along this same line, Laclau and Mouffe's notion of people is not based on an alliance 
between class interests; rather, it stems from an entirely political-discursive articulation that does not favor a priori any element of the social structure over others ${ }^{6}$.

In the light of this suspension in the importance attached to economic relations, we may wonder whether the criticism against politics (as the merely formal and automatic expression of underlying economic relations) should not be supplemented with a critique of the degradation of the economy (as a sphere free from struggles and resistance movements). Likewise, we wonder whether the complete separation between (pure) politics and (pure) economics fails to consider the constituent presence of politics and ideology at the heart of economic practices. Are there any pure relationships of property and possession? And, in spite of its good intentions, doesn't this replicate the neoliberal devices that depoliticize the economy and exclude class struggles from the sphere of politics?

On the other hand, another position postulates that the new working class or multitude does not need to search outside its own productive power for the means to become a political subject capable of overcoming the insurrectional moment and devising a project to oppose the Empire.

This trend underestimates political action, its differential history, and specific logic because, despite certain precautions, it is conceived just as a replica of the economy: the politics of the multitude is based on the fact that a set of common practices and hopes immersed in the winding course of network and computerized production already exists. At this point, we can wonder whether there is an excessive and counterfactual trust in the trend to unity and the resistive hopes of the productive groups that make up the multitude, i.e. an underestimation of the individualization and atomization effects exerted on them by the mechanisms of ideological subjugation and working conditions; and - as some have postulated - a disregard for the conflicting interests that can be found at the heart of the multitude. What if the large majorities that make up the new working class do not tend to the revolution of the common but to individualist consumerism, cynical and apathetic conformism, or the participation in right-wing movements? Shouldn't we develop resistance movements by embarking on a thorough critique based on swimming against the tide of "spontaneous" ideological perceptions?

To conclude, worshiping the potential of masses - and the subsequent underestimation of politics - is not the obverse of the movement of autonomization of politics from the economy? Can we conclude that both

\footnotetext{
${ }^{6}$ The emancipatory theses advanced by Rancière and Badiou sometimes come under criticism for their inaccuracy, for defining politics as a set of extraordinary and revolutionary acts, and for their subsequent underestimation of other forms of struggle and resistance, therefore adhering to a gigantomachia that turns the possible into the sterile. They have also been criticized for ignoring the social reconstruction needed for exceptional political actions to leave their footprint on the inertia of the social construct. Among others, the scheme proposed by Laclau and Mouffe is usually criticized for attaching too much importance to the discursive dimension in the construction of political identities and the idea that postulates that it is possible to materialize an emancipatory project by activating the existing liberal democratic system.
} 
theories lack a deep reflection on the forms of the reciprocal relationship between economy and politics? If we separate politics from any economy-related conditioning factor, don't we risk falling into the omnipotence that humanistic ideas confer upon political subjects? And, if we underestimate the political and ideological struggles of masses as moments when a line is drawn between adversaries and there is an administration of the agglutination of the objective/subjective, antagonistic/non-antagonistic contradictions of heterogeneous social groups with different backgrounds, aren't we at risk of expecting in vain for an automatic process of 'contagion'?

The nationalism/internationalism dilemma also creates sharp divisions. In spite of taking a different formal approach (nomadism, miscegenation, exodus versus the organization under the principles of communism), Hardt and Negri agree with Badiou on the fact that the construction of the emancipatory subject can only take place at a global level: on one hand, not to be left at the mercy of the containment mechanisms of national States; and, on the other, to be capable of facing an economic power that operates across national borders. Conversely, even though Rancière agrees with the diagnosis of a States caught by globalized capital, he still notes that the process of building a people as a claim for equality is always a struggle against a dominant national order and supports the spread of local foci of autonomy - despite their unexpected and volatile nature. Laclau observes that the global link between egalitarian struggles cannot be taken for granted. He focuses on the process: an open-result process inscribed in a chain of equivalence in a global context of multiplication of antagonisms while noticing the potential of political practices adopted in the context of national democracies.

As for autonomy, it is worth noting that, in spite of their profound essential differences, the theoreticians of the multitude agree with Badiou and Ranciére on a key issue related to the "battlefield" of new critical theories: political practice as the ultimate objective of emancipatory struggles can only unfold if fully detached from State institutions and apparatuses.

Politics is diametrically opposed to the State. Mass movements must not get caught in the various mechanisms set by parliamentary or post-democracies to capture and institutionalize them. Only by acting as autonomous forces can they create new and true forms of egalitarian life.

The backdrop of these shared positions is the notion of State-which undoubtedly reminds us of that of Marx and Lenin - as an ideological machine of repression in the service of capital. The difference with the Leninist notion lies, of course, in the fact that now it is not about gaining strength to attack the State; rather, it is about creating counterpower alternatives to enable unprecedented forms of collective democratic organizations that are completely external to State power, even as the ultimate objective of such struggles.

Faced with this defense of emancipation and political subjects that carry on their struggle outside the State, the theoreticians of populism are unwilling to lose ground in liberal democratic States because that 
would mean leaving the field clear for the neoliberal right. The contemporary left should not abandon its emancipatory project; rather, it should reflect upon it as an internal moment of liberal democracy.

As for popular movements, Laclau considers that organizations can neither be completely outside of the State because that would result in political impotence nor entirely inside the sphere of the State because that would lead to their fossilization. Any populist action needs to strike a balance between the horizontal expansion of demands and representative actions for vertical integration around some hegemonic centers.

Far from being an exception oriented only to the formation of emancipatory subjects, populist politics refers to any hegemonic operation to articulate and unify heterogeneous demands. Small struggles, minor victories, demands that result in laws being enacted are as political as the struggles that challenge the existing order. In other words, emancipatory politics always have a populist dimension, but emancipation is not at the heart of all forms of populism.

The notion of State underlying this second position is that of a group of branches and roles that instead of being arranged into a monolithic block are marked by contradictory relationships between different centers of power. Except for forcefully imposed bureaucracies, here the State is a strategic field with multiple antagonisms.

On one front, the State appears as a set of apparatuses that are impervious to popular class struggles. Only fully autonomous groups and struggles are genuinely political. Can the State really have an 'outside' (i.e. a realm of purity)? Isn't this merely the obverse of the belief that considers the State as the only place where political life can truly exist?

On the other front, even though the presence of popular resistance groups within the sphere of the State is acknowledged, the crucial aspect about the fundamental transformation of institutional materiality and State politics as a necessary moment for that presence (asymmetrical with respect to the dominant block) not to end in a discursive gesture is not addressed. At the same time, from this position, it is hard to think about foundational forms of democracy and popular empowerment beyond the parliamentary State.

FUNDING: The author did not receive any external funding.

CONFLICT OF INTEREST: The author declares no conflict of interest. 


\section{REFERENCES}

1. Badiou, Alain. 1982. Théorie du sujet. Paris: Éditions du Seuil. Available at: https://www.persee.fr/doc/homso 0018-4306 1982 num 63 1_2083

2. Badiou, Alain. 1985. Peut-on penser la politique? Paris: Éditions du Seuil. ISBN-10 2020089319

3. Badiou, Alain. 1988. L'être et l'événement. Paris: Éditions du Seuil. ISBN-10 2020098628

4. Badiou, Alain. 2003. "La política a distancia del Estado". Acontecimiento $26: 9-27$.

5. Badiou, Alain. 2007. De quoi Sarkozy est-il le nom? Paris: Éditions Lignes. ISBN-10 2355260036

6. Badiou, Alain. 2013. "Vingtquatre notes sur les usages du mot peuple”. In Qu'est-ce qu'un peuple? Edited by Badiou, Alain, Bourdieu, Pierre, Butler, Judith, Didi-Huberman, George, Khiari, Sadri, Rancière, Jacques, 9-22. Paris: La Fabrique.

7. Badiou, Alain; Gauchet, Marcel. 2014. Que faire? Dialogue sur le communisme, le capitalisme et l'avenir de la démocratie. Paris: Philo editions. ISBN 10: 2953813047

8. Keucheyan, Razmig. 2013. Hémisphère gauche. Une cartographie des nouvelles pensées critiques. Francia: Zones. ISBN 978-2-35522-062-3

9. Hardt, Michael. 2012. "Communism is the Ruthless Critique of all that Exists". Interview conducted $\begin{array}{llll}\text { Praktyka Teoretyczna } & \text { Editorial } & \text { Collective. }\end{array}$ at: https://www.praktykateoretyczna.pl/artykuly/michael-hardt-komunizm-jest-bezwzgledna-krytykawszystkiego-co-istnieje/

10. Hardt, Michael; Negri, Antonio. 2000. Empire. Cambridge: Harvard University Press. ISBN 9780674006713

11. Hardt, Michael; Negri, Antonio. 2001. "La multitude contre 1'empire". Contretemps: 2: 153-166. Available at: http://www.contretemps.eu/wp-content/uploads/Contretemps-02-78-85.pdf

12. Hardt, Michael; Negri, Antonio. 2004. Multitude: War and Democracy in the Age of Empire. London: $\begin{array}{llll}\text { Penguin } & \text { Books. } & \text { ISBN } & \text { Available }\end{array}$ at: https://selforganizedseminar.files.wordpress.com/2011/07/hardt_negri_multitude.pdf

13. Hardt, Michael; Negri, Antonio. 2009. Commonwealth. Cambridge: Harvard University Press. ISBN 978-0-674-03511-9.

Available at: https://ia600204.us.archive.org/11/items/ruidolibrebibliografia/Hardt\%26Negri_Commonwealth.pd $\underline{f}$

14. Inda, Graciela. 2018. "Sujetos políticos y Estado en la geografía de las nuevas teorías críticas”. Revista Reflexiones: 97 (1): 53-64. http://dx.doi.org/10.15517/RR.V97I1.31400 .

15. Inda, Graciela. 2019. "De pueblos, multitudes y populismos: sujetos políticos y transformación social en las nuevas teorías críticas". In Antagonismo, hegemonía y subjetividad, Edited by Ferrari, Florencia and Galafassi, Guido, 95-116. Buenos Aires: Theomai. ISBN: 978-987-22408-5-1. Available at: https://ri.conicet.gov.ar/handle/11336/110604 
16. Laclau, Ernesto; Mouffe, Chantal. 1985. Hegemony and Socialist Strategy: Toward a Radical Democratic Politics. London: Verso. ISBN 1-85984-621-1. Available at: https://libcom.org/files/ernesto-laclau-hegemony-and-socialist-strategy-towards-a-radicaldemocratic-politics.compressed.pdf

17. Laclau, Ernesto. 2000. "Identity and Hegemony: The Role of Universality in the Constitution of Political Logics". In Contingency, Hegemony, Universality Contemporary Dialogues on the Left, edited by Butler, Judith; Laclau, Ernesto; Žižek, Slavoj, 44-89. London-New York: Verso. ISBN 1-85984-757 9.

Available at: https://monoskop.org/images/5/53/Butler_Judith_Laclau_Ernesto_Zizek_Slavoj_Contingency_Heg emony_Universality_2000.pdf

18. Laclau, Ernesto. 2001. "Review: Can Immanence Explain Social Struggles? Reviewed Work Empire by Michael Hardt, Antonio Negri”. Diacritics 31 (4): 2-10. DOI: https://doi.org/10.1353/dia.2004.0008

19. Laclau, Ernesto. 2005. On Populist Reason. London: Verso. ISBN 1-85984-651-3. Available at: https://voidnetwork.gr/wp-content/uploads/2016/09/On-Populist-Reason-by-Ernesto-Laclau.pdf

20. Laclau, Ernesto. 2009. "Laclau en debate: postmarxismo, populismo, multitud y acontecimiento (entrevista por Ricardo Camargo)". Revista de Ciencia Política 29 (3): 815-828. DOI: http://dx.doi.org/10.4067/S0718-090X2009000300007

21. Laclau, Ernesto. 2010. "Posmarxismo y emancipación”. In I Ciclo de Seminarios Internacionales Pensando el mundo desde Bolivia, edit by Negri, Antonio; Dussel, Enrique; Spivak, Gayatri; Wallerstein, Immanuel, 171-178. La Paz: Vicepresidencia del Estado Plurinacional de Bolivia.

22. Mouffe, Chantal. 1993. The Return of the Political. London and New York: Verso. ISBN 0-86091-4860. Available at: https://monoskop.org/images/c/cb/Mouffe Chantal The Return of the Political.pdf

23. Mouffe, Chantal. 2000. The Democratic Paradox. London and New York: Verso. ISBN: 1-85984-7587.

Available at: https://monoskop.org/images/4/41/Mouffe_Chantal_The_Democratic_Paradox_2000.pdf

24. Mouffe, Chantal. 2005. On the Political. London and New York: Routledge. ISBN: 0-415-305209. https://monoskop.org/images/7/75/Mouffe_Chantal_On_the_Political_2005.pdf

25. Mouffe, Chantal. 2018. For a Left Populism. London and New York: Verso. ISBN-13: 978-1-78663755-0. Available: http://www.mcrg.ac.in/Friday Lecture/chantal-mouffe-for-a-left-populism.PDF

26. Negri, Antonio. 2001. “Contrapoder”. In Contrapoder. Una introducción, edited by Fontana, Edgardo; Fontana, Natalia; Gago, Verónica; Santucho, Mario; Scolnik, Sebastián; Sztulwark, Diego, 83-95. Buenos Aires: Ediciones de mano en mano. ISBN 987-96651-3-9. Available at: https:/tintalimon.com.ar/public/5j5x1qt5oeumusgf6flviaxe1wop/Tinta\%20LimonAutores\%20varios-Contrapoder-2002.pdf 
27. Negri, Antonio. 2010. "El movimiento de los movimientos". In I Ciclo de Seminarios Internacionales Pensando el mundo desde Bolivia, edit by Negri, Antonio; Dussel, Enrique; Spivak, Gayatri; Wallerstein, Immanuel, 15-20. La Paz: Vicepresidencia del Estado Plurinacional de Bolivia.

28. Rancière, Jacques. 1981. La nuit des prolétaires: archives du rêve ouvrier. Paris: Fayard. Available at: https://www.persee.fr/doc/hedu 0221-6280_1981_num $13 \quad 1 \quad 3114$

29. Rancière, Jacques. 1995. La mesentente: Politique et philosophie. Paris: Galilée. ISBN : 9782718604503

30. Rancière, Jacques. 1997. "Onze thèses sur la politique”, Filozofski vestnik, XVIII (2). https://ojs.zrcsazu.si/filozofski-vestnik/article/view/3995/3704

31. Rancière, Jacques. 2013. "L'introuvable populisme”. In Qu'est-ce qu'un peuple? edited by Badiou, Alain, Bourdieu, Pierre, Butler, Judith, Didi-Huberman, George, Khiari, Sadri, Rancière, Jacques, 137143. Paris: La Fabrique. ISBN : 978-2-35872-046-5.

32. Rancière, Jacques. 2014. "Potencias y problemas de una política del 99\%: entrevista por Amador Fernández Savater". E1 Diario. January 24. https://www.eldiario.es/interferencias/ranciere-politica-del99132 5060431.html Accessed November 26, 2021.

33. Rancière, Jacques (2016). "Comment sortir de la haine: grand entretien avec Jacques Rancière par Eric Aeschimann". Le Nouvel Observateur, 7 février. Available at: https://bibliobs.nouvelobs.com/idees/20160202.OBS3834/comment-sortir-de-la-haine-grandentretien-avec-jacques-ranciere.html

\section{About the Author, Dr. Graciela Inda}

Degree in sociology. Master in Political and Social Sciences (FLACSO). Doctor in Political and Social Sciences (National University Of Cuyo, Argentina - UNCuyo). Professor of Systematic Sociology, Faculty of Political and Social Sciences (UNCuyo). CONICET (Consejo Nacional De Investigaciones Cientificas y Tecnicas) Researcher (IMESC / IDEHESI / Mendoza Node). Project Director "State, Subjects and Politics in Neoliberal Capitalism" (UNCuyo). Member of the Interdisciplinary Working Group "Social theory and Latin American reality" (CLACSO/ASDI). Research line: State and political subjects in Classical Sociological Theory and Contemporary Critical Theories. Author of numerous articles in international journals. 